Article

\title{
Can Enhancing Efficiency Promote the Economic Viability of Smallholder Farmers? A Case of Sierra Leone
}

\author{
Silvia Saravia-Matus ${ }^{1}$, T. S. Amjath-Babu ${ }^{2, *} \mathbb{D}^{\mathbb{D}}$, Sreejith Aravindakshan ${ }^{2,3} \mathbb{D}^{\mathbb{D}}$, Stefan Sieber ${ }^{4,5}$, \\ Jimmy A. Saravia ${ }^{6}$ iD and Sergio Gomez y Paloma ${ }^{7}$
}

check for

updates

Citation: Saravia-Matus, S.;

Amjath-Babu, T.S.; Aravindakshan, S.;

Sieber, S.; Saravia, J.A.; Gomez y

Paloma, S. Can Enhancing Efficiency

Promote the Economic Viability of

Smallholder Farmers? A Case of

Sierra Leone. Sustainability 2021, 13,

4235. https://doi.org/10.3390/

su13084235

Academic Editor: Hossein Azadi

Received: 18 February 2021

Accepted: 8 April 2021

Published: 10 April 2021

Publisher's Note: MDPI stays neutral with regard to jurisdictional claims in published maps and institutional affiliations.

Copyright: (c) 2021 by the authors. Licensee MDPI, Basel, Switzerland. This article is an open access article distributed under the terms and conditions of the Creative Commons Attribution (CC BY) license (https:/ / creativecommons.org/licenses/by/ $4.0 /)$.
1 Natural Resources Division, United Nations Economic Commission for Latin America and the Caribbean (UN ECLAC), Vitacura, 3477 Santiago, Chile; silvia.saraviamatus@gmail.com

2 International Maize and Wheat Improvement Center (CIMMYT), Dhaka 1212, Bangladesh; sreejiagriman@gmail.com

3 Farming Systems Ecology, Wageningen University and Research (WUR), 6708 PB Wageningen, The Netherlands

4 Leibniz Centre for Agricultural Landscape Research (ZALF), 15374 Muencheberg, Germany; stefan.sieber@zalf.de

5 Thaer-Institute of Agricultural and Horticultural Sciences, Faculty of Life Sciences, Humboldt-Universität zu Berlin, Unter den Linden 6, 10099 Berlin, Germany

6 Center for Research in Economics and Finance (CIEF) and Grupo de Investigación en Banca y Finanzas, School of Economics and Finance, Universidad EAFIT, 050022 Medellín, Colombia; jsaravia@eafit.edu.co

7 Joint Research Center, European Commission, 41092 Seville, Spain; sergio.gomez-y-paloma@ec.europa.eu

* Correspondence: t.amjath@cgiar.org

\begin{abstract}
By developing meta-frontier efficiency and structural equation models, the paper examines whether farm economic viability is positively associated with technical efficiency in a highly food insecure context, such as that of rural Sierra Leone. The findings show that technical efficiency can be a sufficient but not necessary condition in determining economic viability of smallholder farming. It is possible to breach reproductive thresholds at the cost of reduced technical efficiency, when the crop diversification strategy of smallholders includes market-oriented high-value crops. This calls for a dual policy approach that addresses farmers' internal needs for self-consumption (increasing efficiency of food crop production) while encouraging market-oriented cash crop production (diversification assisted through the reduction of associated transaction costs and the establishment of accessible commercialization channels of export related crops and/or high-value crops). The work also calls out for a move-up or move-out strategy for small holders to create viable farming systems in developing world.
\end{abstract}

Keywords: economic viability; technical efficiency; smallholder farmers; Sierra Leone

\section{Introduction}

Agriculture in Sub-Saharan Africa (SSA) suffers from a myriad of challenges, including climate change and water resources scarcity that reduces the efficiency and profitability of its farming systems [1-3], thus making smallholder agriculture increasingly less viable. There is significant interest in transitioning smallholder agriculture in SSA from subsistence level farms into productive and profitable farm enterprises [4]. According to [5], small farmers can prosper through either a "move up" or a "move out" strategy. While some small farmers have the potential to undertake profitable commercial activities in the agricultural sector and expand their farm operation, others should be supported in exiting agriculture and seeking non-farm employment opportunities. To make this decision, the authors argue it is necessary to address the mix of interrelated conditions that threaten smallholder livelihoods, food security, and nutrition. Such conditions include limited human capital, infrastructure, access to markets, and technologies as well as increasingly extreme weather, a lack of social safety nets, and price volatility [6]. To contribute to this discourse, this article 
analyzes the linkages between technical efficiency and the economic viability of subsistence farmers. Throughout this paper, farm technical efficiency is defined as the ability of a farmer to maximize output with given quantities of inputs and a certain technology (output-oriented) or the ability to minimize input usage with a given objective of output (input-oriented) [5]. Thus, this work is related to the "poor but-efficient hypothesis" of [7] but deviates from it as we restrict the examination to the aspect of economic viability of farming alone and do not address poverty per se (which would require the review of all income sources at the farm household level). In this respect, economic viability is mainly connected to the ability of sustaining farm activities from one period to the next. Measuring both technical efficiency and economic viability is useful to understand smallholder behavior, particularly in contexts of resource scarcity. As mentioned by [8], scarcity constraints, rather than any behavioral differences between the poor and nonpoor, can explain the economic choices made by poor households.

Traditionally, farms in SSA are more self-consumption oriented and less market-oriented [9]. It is frequently recommended that there is a need for yield increasing technology as a means to raise overall productivity and output levels [10]. In this context, we study the role of farming efficiencies and market orientation for the economic viability of farmers in Sub-Saharan Africa by focusing on a case study in Sierra Leone. To this end, we use the concept of "reproductive threshold" [11] and the idea of "meta-frontier efficiency" [12] to capture economic viability and efficiency, respectively. In order to understand the efficiency determinants, we use the concept of "capitals" [13] from the sustainable livelihood approach, while economic viability is related to measurements of farm net income [13-15]. A dataset from smallholders in the two most important agricultural regions in Sierra Leone is utilized to understand the linkages among efficiency, market orientation, and economic viability in order to provide policy insights for enhancing the performance and food security of farms in SSA contexts that share similar climate and market structures.

The article is structured as follows: Section 2 introduces the case study region by describing the two dominant farming systems in Sierra Leone and the survey. Section 3 introduces the conceptual framework and methodological approach selected to capture farm economic viability and technical efficiency levels. While efficiency is measured via a DEA Meta Frontier analysis, a Structural Equation Model (SEM) is selected to assess linkages between economic viability and technical efficiency. Section 4 discusses the findings and policy implications. Section 5 concludes.

\section{The Sierra Leone Case Study: Background and Survey}

The eastern and northern regions of Sierra Leone are each associated with two different agricultural production systems (Figures 1 and 2). These agricultural production systems are commonly defined in relation to their agroecological setting, mixes of crop cultivation, and the degree of market integration/self-consumption [16]. Rainforest is the natural vegetation in humid tropical areas of the eastern region, which are sometimes cleared by farmers to grow crops. In contrast, the sub-humid tropics of the northern region is richly covered woodland with medium to tall grass ground cover. Although staple crops (mainly rice) and tubers are grown under shifting cultivation in both agricultural zones, the diversity of commercially grown tree crops vary substantially between the eastern and northern regions. For instance, export-oriented tree crops, such as coffee and cocoa, which benefit from the moisture of the rainforest, are planted in the humid tropics of the eastern region. Relatively less commercialized tree crops, such as oil palm and citrus, are found in the sub-humid areas of the northern region. Sierra Leone, in general, has a humid tropical monsoon climate with two distinct seasons. The rainy season spans from May to October and the dry season spans from November to April. Annual rainfall averages about $3000 \mathrm{~mm}$ (millimeters), ranging from a low of $2000 \mathrm{~mm}$ in the north to a high of $4000 \mathrm{~mm}$ in the south. Average monthly temperatures range from 23 to 29 degrees Celsius, with a maximum of 36 degrees in the lowlands toward the end of the dry season and a minimum of 15 degrees in the highlands at the beginning of the dry season [17]. The impact of 
climate change is already tangible in the agricultural sector. For instance, crop production is affected by prolonged periods of dry days even during the rainy season, while heavy rains in dry season (March) results in excessive weeds growth [18]. Existing climate models predict an increase in average temperatures between 1 and $2.6^{\circ} \mathrm{C}$ by 2060 [19]. Further, Sierra Leone's cocoa farming faces formidable challenges with increasing maximum dry season temperatures, which can significantly reduce the area suitable for cocoa crop [20].

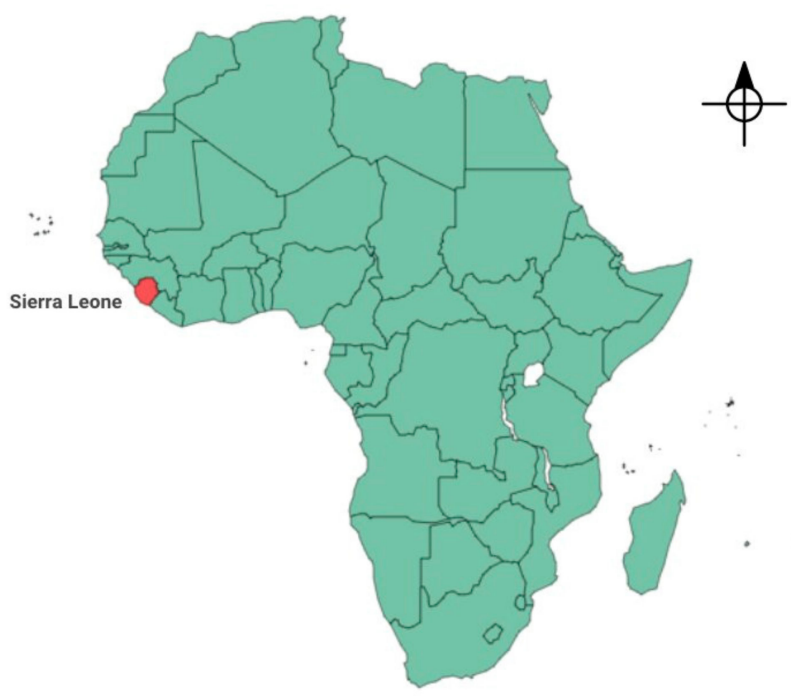

Figure 1. Map of Sierra Leone.

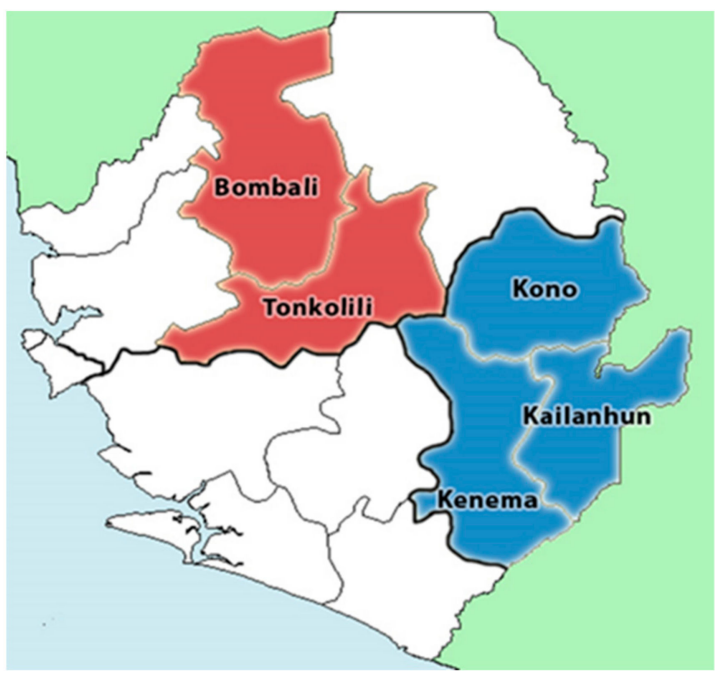

Figure 2. Map of the eastern (blue) and northern regions (red) of Sierra Leone considered in the study. Note: The northern region is dominated by rice farming while the eastern region focuses on cash crop production viz. coffee and cocoa.

According to [21], profitable cash crops can help farmers overcome capital constraints on the purchase of lumpy assets and inputs, which can be used to expand not only cash crops but also food crop production. The flow of capital (from cash to food crops) to purchase fertilizer inputs is partly reflected in rice productivity differentials between farm households in northern and eastern Sierra Leone. Despite agroecological advantages favoring rice cultivation in the northern region, the average rice yield per acre in the eastern region is twice the level of those of the northern region (i.e., 8 to 4 rice bushels per acre, respectively) [22]. Similarly, while up to $65 \%$ of the eastern region's rice production is sold in markets, only a maximum of $30 \%$ of rice output in the northern region is sold [22], 
reflecting a situation of higher food insecurity among farm household in the latter region. Overall, farm income levels per acre in the eastern region are estimated to be around three times higher than in the northern region [14]. That is, net farm income per acre per year in the northern region is reported to average of SLL 190,000 (USD 57) while those in the eastern region average SLL 506,000 (USD 149) (based on 2009 survey-based prices) [14].

Despite the different crop portfolios and associated farm income levels across the two main agricultural regions of Sierra Leone, two-thirds of farm households in Sierra Leone cultivate up to 12 different crops on plots that average 2 acres [16]. Empirical evidence shows that the widespread adoption of crop diversification strategies is a food security objective, with the presence of inefficient input/output mixes seeming to favor risk minimization over cash-income generation [14,22,23]. The latter is aimed at securing self-consumption needs over production expansion and productivity increase. Ultimately, this relates to insufficient access to key assets and capital. Farm households in Sierra Leone have limited physical (equipment) and financial (credit) capitals, disincentivizing improved crop management. For example, when making investments in agricultural equipment, smallholders in Sierra Leone confront not just a credit shortage, but also village-level institutional arrangements that do not support using land as collateral for loans [22]. For instance, the notion that the enlarged farm-household family (including the dead and the unborn) must agree to land transactions represents a significant bottleneck [24]. Additionally, only basic agricultural equipment and tools (i.e., hand-hoe) are available, while the transport and storage infrastructure is also largely inadequate [14]. These precarious conditions increase pre- and post-harvest losses, reaching up to $30 \%$ of total output in most rural areas [22].

Although land expansion is usually constrained by insufficient labor availability to conduct land clearing and preparation under shifting cultivation, soil fertility is also sharply declining due to ineffective fallow practices that reduced the required land regeneration period [22]. These fallow periods vary between 4 and 7 years instead of the required length of 25 to 30 years [25]. Human and social capital are also restricted in the sense that access to health, agricultural education, and training are limited while networking capacity and information access are usually restricted to male farm household heads of traditional/prominent families and village leaders [24].

This analysis presented in the study is based on primary data collected through 600 face to face interviews implemented in 2009 by the Joint Research Centre of the European Commission [22]. The survey questionnaire contained four segments of relevance to the present study: 1. Identification Information: Region, district, chiefdom, section, village, and household number. 2. Household demographic (per occupant): Gender, age, main economic activity (agriculture, petty trading, paid employment, artisan, other), sources of income, and ranking of relative importance (farm output, livestock, remittances, gifts, off-farm activities). 3. Social Capital (of household head): position in the community (section chief, village, chief, village headman, tribal authority, ordinary citizen, "stranger," other), membership in any farmer association (position in the association and number of memberships), perception of benefit gained from belonging to any organization (great, little, none). 4. Farm Characteristics: Types of crops and cultivated area (between January and December 2008) as well as any changes in planted area with respect to previous year, type of agricultural practices undertaken (yes-no: use of manure, soil cover, crop rotation, intercropping, fallowing, etc.), quality and availability of seeds, use of storage facilities (percentage of output stored and for how long), threats to farm production (plant disease or rain variations), and infrastructure (distance between plots, quality of roads, market access, and project office, etc.) [22].

To obtain an accurate understanding of the nature of the smallholder agricultural production, the 600 farm households observed in the survey were drawn from the most relevant agricultural areas of Sierra Leone. The sample represents the two main agricultural areas in the country: food crop cultivation (largely rice growers concentrated in the northern region and accounting for two-thirds of the sample) and cash tree cropping (i.e., coffee and 
cocoa in the eastern region). Sub-sample sizes of the two regions were based on existing population densities for these areas in Sierra Leone. These are representative observations based on the agricultural population in both regions (northern and eastern), five districts (Tonkolili, Bombali, Kono, Kenema, and Kailahun), 11 chiefdoms, and 39 villages. Besides its representativeness and the pertinence of the data, another main advantage of the survey is that it covers all forms of smallholder agricultural systems in Sierra Leone, with observations of all major agro-ecologies: the upland forest tree cropping system, the upland food cropping system, and the lowland (inland valley swamp and Boliland) food cropping system [23]. During the analyses of the 600 farm households surveyed, 25 were dropped due to data inconsistencies. At present, this is still the major survey that effectively captures socio-demographic traits, economic performance, and detailed agricultural management data at farm-household level in all major agro-ecologies of Sierra Leone. Agricultural management data collected here is the essential information for capturing smallholder efficiency and economic viability and conducting the analysis proposed in this paper.

\section{Conceptual Framework and Methodological Approach}

This section addresses the selected theoretical and econometric approaches to explore the relationship between economic viability and technical efficiency within farm households in the two dominant agricultural production systems in Sierra Leone.

\subsection{Economic Viability}

Economic viability is a concept that refers to the adeptness with which resources are employed in the production process at a given period [26]. In order to understand economic viability of farm households, the concept of reproductive threshold (RT) [11] is used. The concept of Reproductive Threshold (RT) is employed for assessing the viability of different farming or production systems. Economic viability of farming systems belonging to different agroecologies or geographies can be compared based on net farm income (NFI) and RT. Assuming that there are two hypothetical regions, 1 and 2, with different farming systems and crop management practices, then the farming system in region- 1 can be said to be more economically viable than the farming system in region-2 provided the difference between net income per household unit to RT of former (region 1) is greater than the latter (region 2) at a given point in time. The RT is the minimum net farm income (NFI) per household working unit (HWU) that would allow a farmer to pay for all inputs, restore capital productivity, and begin a new production cycle. The RT refers to the reproduction of family manpower and the means of production. A negative difference between farm net income (FNI) and RT (FNI < RT) per household working unit (HWU) implies that the farming system in question is not economically viable and risks going out of business. In such situations, without any additional off-farm income, farms can survive only in the short run (few agricultural cycles) by underpaying labor and/or by not replacing the capital depreciation. In the medium-to-long run, however, these survival strategies will inevitably exclude some farms from the market [14].

RTs differ by region within the same country, particularly if regions are characterized by different crop portfolios, market integration, input usage, infrastructure, on/off-farm job opportunities, and technology access. These components influence the way in which production and opportunity costs are calculated. For the two regions surveyed in Sierra Leone, two different RTs were identified and farm viability assessments were separately undertaken. For the northern region, where farmers have barely any opportunity to secure an agricultural wage (outside community labor sharing/exchange schemes), it was assumed that the RT (north) is equal to zero. In other words, as long as farmers manage to cover farm input costs, farm activity is deemed viable since no other labor engagement is readily available to serve as a replacement or alternative; i.e., zero labor opportunity costs. For the eastern region, where some non-own-farm work opportunities can be found during the harvesting of cash tree crops, RT (East) was set at the average annual agricultural wage locally attainable equal to SLL 700,000 [14]. A positive difference between NFI and RT 
(North or East) indicates that the farm provides (i) a minimum satisfactory livelihood for the farmer, and (ii) a basic coverage of farm costs in the northern region or a surplus of capital accumulation in the eastern region. A negative difference means that the farm does not provide an investment opportunity or an acceptable living standard that could support a minimum level of self-consumption. Hence, the farm is not viable. In this work, the farm units above the threshold are taken to be economically viable.

\subsection{Efficiency Analysis: A DEA-Meta-Frontier}

Farm efficiency is captured by comparing the levels of farm output produced to farm inputs used. Technical efficiency improvement is the ability of an economic unit to produce a higher level of output for a given set of inputs [27]. While both parametric (stochastic frontier analysis) and non-parametric (data envelopment analysis) approaches have been used to examine technical efficiency, the meta-frontier approach used in this study is based on an input-oriented data envelopment analysis (DEA) model [28] to estimate technical efficiency scores. Advantages of using DEA include the fact that there is no requirement to specify a functional form $[29,30]$. DEA is based on a linear programming technique that calculates the efficient (or best practice) frontier of decision making units (DMUs) through a piece-wise linear envelopment of observed input-output combinations, with assumptions concerning scaling and disposability of the inputs and outputs [31]. The DEA method is widely applied in economics, operations research, and agriculture; as such, further discussion of DEA is limited in this article.

The technical efficiency of DMUs (e.g., individual farms) is the ratio of actual productivity (output per unit of input) and frontier (i.e., best practice) productivity [32]. A farm is said to be technically efficient (input-oriented), if it maintains the current output level (crop yield) using the minimum possible quantity of inputs, including labor, capital, and technology (fertilizer, agrochemicals, seeds, and tillage) [33]. If a DMU's actual productivity is equal to frontier productivity (i.e., it lies on the frontier), it is considered to be perfectly technically efficient; in contrast, if its actual productivity is less than the frontier productivity (lies below the frontier), it is considered technically inefficient.The efficient DMUs, as defined by DEA, may not necessarily form a "production frontier," but rather lead to a "best-practice frontier" [34].

However, calculating a single frontier for all farms in Sierra Leone regardless of whether these operate in the northern and eastern regions would assume that all farmers have access to the same technology and operate under equal agroecological conditions and markets, thus the differences in production conditions would be falsely interpreted as efficiency changes due to technology applied. Thus, we employ a DEA meta-frontier approach $[12,35,36]$ that involves: (1) estimation of regional group frontiers with technology discrimination and (2) estimation of common frontier by pooling the input-output data of all the samples $(\mathrm{N}=575)$ without any technology differentiation. The distance between $\theta_{i}$ and $\theta_{i}^{*}$ represents the technology gap for the $i^{\text {th }}$ farm, where $\theta_{i}$ and $\theta_{i^{*}}$ are the common meta-frontier TE and Regional Group frontier TE of the $i^{\text {th }}$ farm, respectively. The metatechnology ratio (MTR) is given by the ratio of $\left(\theta_{i}\right) /\left(\theta_{i^{*}}\right)$. In Figure 3 , there are two groups operating at different technology levels (represented by frontiers: $1,1^{\prime}$ and $2,2^{\prime \prime}$ ). The common meta-frontier is represented by $\mathrm{M}, \mathrm{M}^{\prime}$. 


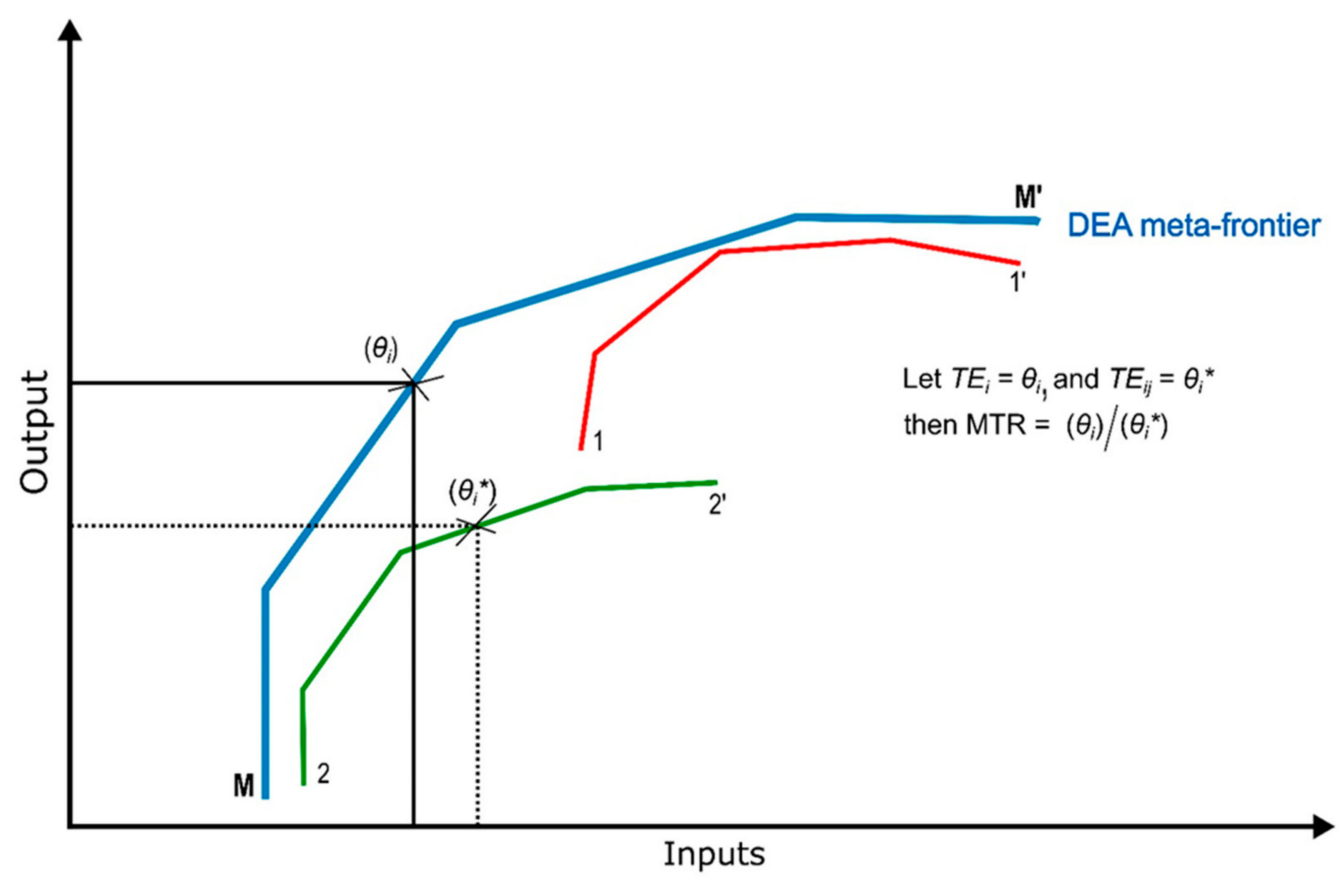

Modified by authors after Aravindakshan et al. 2018

Figure 3. Meta and group efficiency frontiers.

Step 1: Estimation of Group Frontiers with Technology Discrimination

Consider a sample of ' $\mathrm{N}$ ' farms operating in one of the two regions. Each of these farms is seen as a decision-making unit (DMU) that transforms input resources into products and services. Assume that the $j^{\text {th }}$ farm $\left(\mathrm{DMU}_{\mathrm{j}}\right)$, produces $\mathrm{m}$ outputs $\left(y_{i j} \ldots \ldots \ldots \ldots \ldots \ldots \ldots y_{m j}\right)$ by using ' $k$ ' inputs $\left(x_{i j} \ldots \ldots \ldots \ldots \ldots \ldots \ldots \ldots x_{k j}\right)$.

It is assumed that the observed revenue serves as an unbiased estimate of the true output of the farm. In its generalized form, TE is simply the weighted sum of outputs/weighted sum of inputs, represented by $\theta$. To optimize TE, we assume that each farmer chooses a vector of inputs and output weights. Hence, Equation (1) may be rewritten for $q^{\text {th }}$ farm as:

$$
\theta_{q}=\frac{\sum_{r=1}^{z} u_{o} y_{r q}}{\sum_{i=1}^{m} v_{p} x_{i q}}
$$

where ' $u_{0}$ ' and ' $v_{p}$ ' are weighted sum of outputs " $\mathrm{m}$ " and inputs " $\mathrm{k}$ ", respectively, $u_{0}$, $o=1,2,3, \ldots \ldots \ldots, \mathrm{m}$, and ' $v_{p}{ }^{\prime}, p=1,2,3, \ldots \ldots \ldots, \mathrm{k}$. The $(\mathrm{k} \times \mathrm{N})$ input matrix " $\mathrm{X}$ " and $(\mathrm{m} \times \mathrm{N})$ output matrix " $\mathrm{Y}$ " represent data for all the $\mathrm{N}$ farms in the sample and each farm belongs to one of two different farming systems or regions. There are two farming systems, one from the eastern region and another from the northern region such that $j=1$, 2. The present study, $\mathrm{k}=7$ inputs and $\mathrm{m}=1$ output (net farm revenue) are represented in the DEA input-output model (Table 1). The seven inputs modeled are as follows: (1) area of the farm (A); (2) cost of hired labor for food crops (hlf); (3) cost of hired labor for tree crops (hlt); (4) cost of family labor for food crops (flf); (5) cost of family labor for tree crops (flt); (6) cost of seed for food crops (sf); (7) seed/sapling cost for tree crops (st). 
Table 1. Descriptive statistics of variables used in the technical efficiency model.

\begin{tabular}{|c|c|c|c|c|}
\hline \multirow{3}{*}{ Variables } & \multicolumn{4}{|c|}{ Agricultural Production Systems } \\
\hline & \multicolumn{2}{|c|}{$\begin{array}{l}\text { Farmers in the Eastern Region } \\
\qquad[N=186]\end{array}$} & \multicolumn{2}{|c|}{$\begin{array}{l}\text { Farmers in the Northern Region } \\
\qquad[N=389]\end{array}$} \\
\hline & Mean & Std. Dev & Mean & Std. Dev \\
\hline \multicolumn{5}{|c|}{ Input Variables in Technical Efficiency Model (Acres, SLL) } \\
\hline Area of farm & 15.66 & 11.04 & 7.24 & 5.75 \\
\hline Cost of hired labor for food crops (hlf), & $1,813,334.00$ & $1,828,343.00$ & $1,977,900.00$ & $1,901,616.00$ \\
\hline Cost of hired labor for tree crops (hlt), & $2,721,325.00$ & $10,877,240.00$ & $735,167.60$ & $1,329,612.00$ \\
\hline Cost of family labor for food crops (flf), & $1,757,734.00$ & $3,266,463.00$ & $736,163.30$ & $1,113,296.00$ \\
\hline Cost of family labor for tree crops (flt), & $2,127,242.00$ & $6,251,524.00$ & $421,542.20$ & $718,998.80$ \\
\hline Cost of seed for food crops (sf) & $3,701,234.00$ & $5,379,813.00$ & $2,203,627.00$ & $3,452,357.00$ \\
\hline Cost of seed/sapling for tree crops (st) & $7,345,557.00$ & $35,799,740.00$ & $56,832.96$ & $498,399.30$ \\
\hline \multicolumn{5}{|c|}{ Output variable in technical efficiency model (SLL) } \\
\hline Annual farm income & $8,040,856.00$ & $10,643,800.00$ & $1,697,363.00$ & $51,356,930.00$ \\
\hline
\end{tabular}

The basis for all the analytical work described herein is the basic DEA model proposed by [37], often referred to as the "CCR" model. The CCR model for the $i^{t h}$ farm in the $j^{\text {th }}$ group of the input-oriented model can be represented in Equation (2). We chose the input oriented DEA model because smallholder farmers in Africa generally have more control on the use of inputs than the outputs [38]. For example, net revenues are subject to market and price volatility that are beyond the control of farmers in Serra Leone.

$$
\operatorname{Min}_{\theta_{i j}} \theta \text {, given } \mathrm{j}=1,2
$$

subject to:

$$
-y_{i j}+Y \lambda \geq 0 \theta_{x_{i j}}-X \lambda \geq 0
$$

where $\theta$ are technical efficiency (TE) scores and $\lambda$ is an $(\mathrm{N} \times 1)$ vector of weights corresponding to peer weights. For the $i^{\text {th }}$ farm of the $j^{\text {th }}$ group, these are represented by vectors $x_{i j}$ and $y_{i j}$, respectively. TE scores $(\theta)$ are calculated by constraining the ratio outputs/inputs to a range of 0 to 1 , and then assigning weights to the inputs and outputs in order to maximize $\theta$ such that the TE of the $j^{\text {th }}$ group is obtained by solving for Equation (2).

As presented above, the input oriented CCR model Equation (1) operates under an assumption of constant returns to scale (CRS). When the rate of change in outputs is slower than the rate of change of inputs applied, the DMUs may exhibit non-increasing returns to scale (NIRS). In such conditions, the restriction $\lambda \leq 1$ may be set in Equation (2) [39]. However, we assume that the farm production in the smallholder-dominated production systems of Sierra Leone is assumed to operate under variable returns to scale. The VRS assumption means either (a) increasing returns to scale; i.e., scaling up all farm inputs by $\alpha$ percent leads to an increase in output of more than $\alpha$ percent or (b) decreasing returns to scale; i.e., increasing all inputs by $\alpha$ percent leads to an increase in output of less than $\alpha$ percent. In the case of agriculture, increased amounts of inputs often do not proportionally increase the amount of outputs [40]. Thus, the CCR model is modified [28] to operate under VRS by introducing an additional convexity constraint to Equation (2):

$$
\sum_{j=1}^{n} \lambda_{i j}=1
$$

The empirical model is as follows:

$$
T E_{i j}=\min _{\theta_{i j}^{V R S} \lambda} \theta_{i j}^{V R S} \text { subject to } Y_{i j} \leq Y \lambda ; \theta_{i j}^{V R S} X_{i j} \geq X \lambda ; \geq 0, \text { given } \sum_{j=1}^{n} \lambda_{i j}=1
$$


where $Y$ and $X$ are the output (yield) and input vectors, respectively, and $\theta_{i j}^{V R S}$ is the TE score of the $i^{\text {th }}$ farm under VRS. Normally, $0 \leq \theta_{i j}^{V R S} \leq 1$. For any technology group $\mathrm{j}$, the average VRS technical efficiency score lies between $0 \leq \theta_{j}^{V R S} \leq 1$; however, if all the farms in the group are on the production frontier, then $\theta_{j}^{V R S}$ equals 1 and the entire group is technically efficient. Ref. [41] state that some authors distinguish "total" or "overall" technical efficiency (i.e., Equation (1)) from "pure" technical efficiency (i.e., Equation (2)). The simple calculation $1-\theta_{i}^{V R S}$ measures inefficiency as the distance from the efficiency frontier to the current efficiency level of the $i^{\text {th }}$ farm.

\section{Step 2: Estimation of Common Meta-Frontier}

Given that each farming system, represented by the regions in the case of Sierra Leone, uses different production technology, then it is clear from Figure 3 that the common metafrontier can encompass input/output combinations of the two farming systems under scrutiny. In addition, although the conceptual diagram shows smooth frontiers for both meta-frontier and group frontier, our estimation procedure is based on piece-wise linear frontiers as shown in Equations (2) and (4). As with the DEA model in step 1, the procedure can easily be extended to the data set by pooling all samples. Thus, the deterministic meta-frontier DEA model for all farms under different farming systems can be expressed as follows:

$$
T E_{i}=\min _{\theta_{i}^{V R S} \lambda} \theta_{i}^{V R S} \text { subject to } Y_{i} \leq Y \lambda ; \theta_{i}^{V R S} X_{i} \geq X \lambda ; \lambda \geq 0, \text { given } \sum_{\mathrm{i}=1}^{\mathrm{n}} \lambda_{\mathrm{i}}=1
$$

The meta-technology ratio (MTR) measures the proximity of a group frontier to the common meta-frontier; it is also known as the meta-technology ratio. The MTR is computed as the ratio of output for the $j^{\text {th }}$ group, relative to the potential output defined by the meta-frontier function given the observed inputs [12]. It captures productivity differences between the meta-frontier technology and respective group frontier technology, and is expressed as:

$$
\mathrm{MTR}=T E_{i} / T E_{i j}
$$

In the present study, the MTR highlights (for each farming system) the distance between the group-specific efficiency frontier and the meta-frontier. It is indicative of the efficiency improvement potential of farms, in a specific farming system group, that would be possible if they were given access to the management practices of the other farm group. For example, a relatively low average MTR for a specific group suggests a wide technological gap between the farms in that group in relation to the meta-frontier. In such a case, significant improvements in technical efficiency can potentially be realized by switching to a different technology that has a higher MTR.

\subsection{Regression Analysis: Structural Equation (SEM) Model}

The inter-relatedness of economic viability and efficiency is long recognized in economics literature [26]. There is a renewed interest in the joint-estimation of economic viability and efficiency in sustainability studies on various fields including energy [42], and agriculture $[43,44]$. Therefore, the best model should be the one that considers the metafrontier efficiency as a latent variable to reproductive threshold representing economic viability. An econometric technique that allows such a relationship among variables is the structural equation model (SEM). SEM is optimal for exploring the relation between the ability of the farm household to breach the reproduction threshold and its technical efficiency score.

Let $Y_{1}^{*}$ be a binary variable representing reproductive threshold and $Y_{2}^{*}$ be the metafrontier efficiency scores, respectively. Then, measurement model of SEM (following [45]) has two equations:

$$
Y_{1 i}^{*}=X_{1 i} B_{1}+u_{1 i}
$$




$$
Y_{2 i}^{*}=X_{2 i} B_{2}+u_{2 i}
$$

where $u_{1}$ and $u_{2}$ are with zero mean and covariance matrices of $\Sigma \mathbf{u}_{11}$ and $\Sigma \mathbf{u}_{22}$, respectively, and are uncorrelated with each other. The latent model is

$$
Y_{1 i}^{*}=\varnothing Y_{1}+G Y_{1 i}^{*}+I X_{1 i}+\omega_{i}
$$

SEM specifies the reproductive threshold and efficiency scores as a function of determinants related to human, social and physical capitals and livelihood strategies along with any technical support received from an external agency (see Table 2). Constraints on access to capital can limit the capacity of farmers to efficiently utilize inputs and secure maximum possible output. Specifically, physical capital is represented by access to post- harvest storage; human capital is represented by age and education of farm household heads; social capital is measured in terms of whether the farm household head is male or female; financial capital is excluded because no access to credit or other forms of financial support to farm production were recorded. Crop diversification (inverse Simpson index for crops), presence of livestock at farm level, fallow practices, and the extent of household head labor involvement in the farm are used to represent livelihood strategies, as these represent, to a certain extent, decisions taken at the farm household level regarding production and production potential. In other words, livelihood strategies, in this rural context, refer to the choices made to preserve existing assets and income [46].

\begin{tabular}{|c|c|c|c|c|c|c|}
\hline \multirow{2}{*}{\multicolumn{3}{|c|}{ Numerical Variables }} & \multicolumn{2}{|c|}{ Eastern Region [N = 186] } & \multicolumn{2}{|c|}{ Northern Region [N $=389]$} \\
\hline & & & \multirow{2}{*}{$\begin{array}{l}\text { Mean } \\
50.28\end{array}$} & \multirow{2}{*}{$\begin{array}{c}\text { Std. Dev } \\
14.89\end{array}$} & \multirow{2}{*}{$\begin{array}{c}\text { Mean } \\
47.1\end{array}$} & \multirow{2}{*}{$\begin{array}{c}\text { Std. Dev } \\
13.99\end{array}$} \\
\hline Human capital & Age & $\begin{array}{l}\text { Age is related to farming } \\
\text { experience }\end{array}$ & & & & \\
\hline Human capital & Education & $\begin{array}{l}\text { Education is expected to } \\
\text { contribute to decision } \\
\text { making capacity }\end{array}$ & 2.8 & 4.4 & 2.7 & 6.6 \\
\hline Physical capital & $\begin{array}{c}\text { Postharvest } \\
\text { storage facility }\end{array}$ & $\begin{array}{l}\text { Percentage of } \\
\text { output stored }\end{array}$ & 20.36 & 16.5 & 21.34 & 17.7 \\
\hline $\begin{array}{l}\text { Livelihood } \\
\text { strategy }\end{array}$ & Fallow & $\begin{array}{l}\text { Number of years } \\
\text { under fallow }\end{array}$ & 10.57 & 6.4 & 6.24 & 3.3 \\
\hline $\begin{array}{l}\text { Livelihood } \\
\text { strategy }\end{array}$ & $\begin{array}{l}\text { Inverse Simpson } \\
\text { Index }\end{array}$ & $\begin{array}{l}\text { Crop concentra- } \\
\text { tion/Diversification }\end{array}$ & 4.18 & 1.18 & 2.9 & 1.1 \\
\hline \multirow{2}{*}{\multicolumn{3}{|c|}{ Categorical Variables }} & \multicolumn{2}{|c|}{ Eastern Region [N = 186] } & \multicolumn{2}{|c|}{ Northern Region [N = 389] } \\
\hline & & & 0 & 1 & 0 & 1 \\
\hline Social capital & Gender & $\begin{array}{l}\text { Household head is male } \\
\text { or female }\end{array}$ & 0.17 & 0.38 & 0.27 & 0.44 \\
\hline $\begin{array}{l}\text { Livelihood } \\
\text { strategy }\end{array}$ & Part Time Farmer & $\begin{array}{c}1 \text { if Farm-household Head } \\
\text { is a part time farmer; } 0 \text { if } \\
\text { Full Time Farmer }\end{array}$ & 0.027 & 0.16 & 0.12 & 0.32 \\
\hline $\begin{array}{l}\text { Livelihood } \\
\text { strategy }\end{array}$ & Livestock & $\begin{array}{l}\text { Integration of livestock to } \\
\text { cash or food crop farming }\end{array}$ & 1.32 & 2.25 & 0 & 0 \\
\hline
\end{tabular}

Table 2. Variables used in the Structural Equation Model: Description and Descriptive Statistics.

The measurement models specified in Equations (6) and (7) are specified as follows:

ReproductionThreshold (aboveorbelowthethresholdcodedas1/0)

$=f($ Meta FrontierEfficiency, Age, Education, Gender, Storage, PartTimeFarmer, Livestock, FallowPractices, Inverse, SimpsonIndex)

MetaFrontierEfficiency $=f($ Age, Education, Gender, Storage, PartTimeFarmer, Livestock, FallowPractices, InverseSimpsonIndex, TechnicalSupport 
While the DEA-metafrontier analysis is performed using the $\mathrm{R}$ software package "Benchmarking" [47], we use "Lavaan" package in R for structural equation modeling. The model estimation is done using nonlinear minimization subject to box constraints. A Yuan-Bentler correction is applied to the estimates to obtain unbiased test-statistics.

\section{Findings and Discussion}

First, the results of the meta-frontier DEA analysis is discussed, which is then followed by the results of structural equation model.

\subsection{Results of Meta-Frontier Efficiency Analysis}

Group frontier efficiency estimates for each farming systems considered are reported in Table 3; note that they only provide an indicator of the TE with which each of the farms is operating within their respective technological group. For farms in the eastern region, scores range from a low of 0.27 to a maximum of 1.0 (mean $=0.74$ ), while for farms in the northern region, the range is 0.1 to 1.0 (mean $=0.49$ ). In other words, the group-frontier efficiency score shows that the mean gap between the best farmer in the eastern regional frontier and other farmers in the eastern region in the sample (186) is about $26 \%$. The same between the best farmer in the northern regional frontier and other farmers in the northern region in the sample (389) is about $51 \%$.

Table 3. Meta-frontier, group-frontier and technology gap of farming systems.

\begin{tabular}{ccc}
\hline & Farms in the East [N = 186] & Farms in the North [N = 389] \\
\hline Meta-frontier efficiency & $0.58^{* * *}(0.29)$ & $0.34(0.27)$ \\
Group-frontier efficiency & $0.74^{* * *}(0.22)$ & $0.49(0.24)$ \\
Meta-technology ratio a & $0.76^{* * *}(0.24)$ & $0.69(0.31)$ \\
\hline
\end{tabular}

Notes: ${ }^{* * *}$ Null of equality of efficiency distributions of farming systems in east and north are rejected at $0.1 \%$ levels. Test statistic from 5000 bootstrap replications. A meta-technology ratio (MTR) represents the technology gap between farming systems.

The wider range of technical efficiency scores of northern farms compared to the relatively narrow TE range for eastern farms indicates a high level of operational heterogeneity among northern farmers. On average, within their respective groups, the northern farmers could produce the same level of output consuming 51\% less inputs. The farming systems in the east, on average, may reduce $26 \%$ of the current input use to produce on par with their group frontier farms. Note that while the wide range of group-specific TE scores within a specific group is indicative of the variation between the generally followed practices in the region and the actual farm level implementation of an individual farmer in that region, group-specific efficiency measures do not allow for comparing across farmers in north and east. Hence, the TE of farmers in north and east is compared based on the meta-frontier estimates.

Further to estimating the group-frontier, we test whether the efficiencies of the selected farming systems in the two regions really differ between them. For this, we use an adapted Li-test $[48,49]$, where the null of equality of efficiency distributions is rejected at $0.1 \%$ level (Tn: 24.18; $p$-value: $<0.001$ ), indicating a significant difference between the region-specific efficiencies of the farming systems. Consequently, it shows that the differences among the two regions are statistically significant and it is appropriate to evaluate their efficiency using the meta-frontier approach.

Results in Table 4 show a large variation in the estimated efficiency scores across and within the two regions. In order to explain the relative position of the farm with respect to the meta-technology efficiency frontier, these scores are clustered into ten groups: $0-10,11-20,31-40,41-50,51-60,61-70,71-80,81-90$, and $91-100 \%$. For farming systems in the east (commercial-cash crop production-oriented farms), the average meta-frontier technical efficiency score is 0.58 (Table 3), indicating a potential reduction in input use by approximately $42 \%$ to produce the current level of output, relative to the frontier farms 
in the pooled sample $(\mathrm{N}=575)$. When assessed based on the meta-frontier, the average meta-technology ratio in this region is 0.76 . This means that the potential reduction in farm input use is about $24 \%$ of that of the farms lying on the meta-frontier (i.e., Eff $=1.0$ ).

Table 4. Range of meta-frontier efficiency of farming systems under VRS assumption.

\begin{tabular}{ccccc}
\hline \multirow{2}{*}{$\begin{array}{c}\text { Efficiency Index } \\
\text { Range (\%) }\end{array}$} & \multicolumn{2}{c}{ Farms in the East [N = 186] } & \multicolumn{2}{c}{ Farms in the North [N = 389] } \\
\cline { 2 - 5 } & Frequency & $\mathbf{( \% )}$ & Frequency & $\mathbf{( \% )}$ \\
\hline $0.0-10.0$ & 0 & 0.00 & 20 & 5.14 \\
$11.0-20.0$ & 11 & 5.91 & 154 & 39.59 \\
$21.0-30.0$ & 29 & 15.59 & 58 & 14.91 \\
$31.0-40.0$ & 16.13 & 38 & 9.77 \\
$41.0-50.0$ & 22 & 11.83 & 38 & 9.77 \\
$51.0-60.0$ & 17 & 9.14 & 21 & 5.40 \\
$61.0-70.0$ & 15 & 8.06 & 13 & 3.34 \\
$71.0-80.0$ & 11 & 5.91 & 4 & 5.03 \\
$91.0-100.0$ & 11 & 5.91 & 21 & 5.60 \\
100.0 & 40 & 21.51 & 22 & \\
\hline
\end{tabular}

For northern farms (subsistence rice- producing farms), the mean technical efficiency is 0.35 when assessed based on the meta-frontier and the average meta-technology ratio of these farms is 0.69 (Figure 4). This, when interpreted relative to a farm producing at the frontier and represented by the meta-technology of the pooled sample, indicates a potential reduction possibility of $65 \%$ of inputs to maintain the current level of output production (Figure 4). Now turning on to the frontier farms $(E f f=1.0)$, there are a total of 40 farms from the east producing at the frontier, while only 22 northern farms are on the frontier (Figure 4).
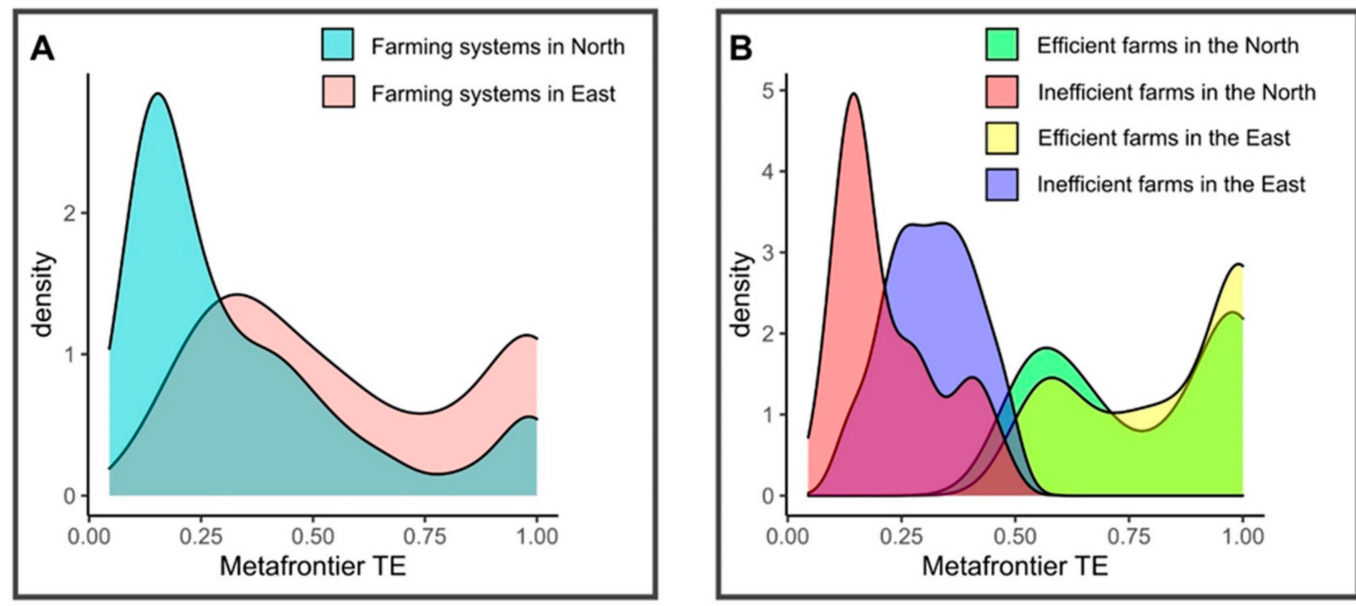

Figure 4. Meta-frontier technical efficiencies of farm households in Sierra Leone. Panel (A) shows the range of efficiencies for farming systems in the two study regions. Panel (B) corresponds to the efficiency distribution of inefficient and efficient farms in the north and east of the country.

Further, the meta-technology ratio of technical efficiency in the east is significantly higher than it is in the northern region (0.69); the meta-technology ratio in the east remains above 0.76 during the sample period (Table 3 ). Thus, the eastern provinces possess the best input utilization technology. The eastern farms are commercial farms engaged in cash crop production for the market, thus having better crop management systems compared to farms in the northern region. This is consistent with the fact that the districts in the east show high efficiency under the group frontier and the meta-frontier. 


\subsection{Results of Regression Analysis}

The findings of the structural equation model are presented in Table 5. The model fits the data given the chi square statistic. MFTE and RT are latent (dependent) variables. In the second step of SEM, MFTE becomes a manifest variable of RT.

Table 5. Results of structural equation model (SEM) showing the relationship between MFTE and RT.

\begin{tabular}{|c|c|c|c|c|}
\hline \multicolumn{5}{|c|}{ Meta-Frontier Technical Efficiency (MFTE) } \\
\hline & Est. & $\mathrm{SE}$ & Z-value & $p(>|z|)$ \\
\hline Inverse Simpson index & $-0.017^{* *}$ & 0.01 & -2.167 & 0.030 \\
\hline Livestock & -0.005 & 0.00 & -1.080 & 0.280 \\
\hline Age & -0.001 & 0.00 & -0.922 & 0.357 \\
\hline Education & 0 & 0.00 & 0.246 & 0.805 \\
\hline Sex/Gender & 0.043 & 0.03 & 1.681 & 0.093 \\
\hline Part-time farmer & $0.095^{* *}$ & 0.05 & 2.107 & 0.035 \\
\hline Fallow practices & $-0.007^{* * *}$ & 0.00 & -4.435 & 0.000 \\
\hline Technical Support & -0.001 & 0.04 & -0.038 & 0.970 \\
\hline $\begin{array}{c}\text { Postharvest storage } \\
\text { facility }\end{array}$ & -0.001 * & 0.00 & -1.908 & 0.056 \\
\hline \multicolumn{5}{|c|}{ Reproductive Threshold (RT) } \\
\hline Inverse Simpson index & $0.031^{* * *}$ & 0.01 & 2.921 & 0.004 \\
\hline Livestock & -0.009 & 0.01 & -1.261 & 0.208 \\
\hline Age & 0.001 & 0.00 & 0.711 & 0.477 \\
\hline Education & -0.001 & 0.00 & -0.417 & 0.677 \\
\hline Sex/Gender & 0.001 & 0.03 & -0.004 & 0.997 \\
\hline Part-Time Farmer & $-0.119^{* *}$ & 0.06 & -2.003 & 0.045 \\
\hline Fallow Practices & $0.005^{* * *}$ & 0.00 & 3.268 & 0.001 \\
\hline $\begin{array}{l}\text { Postharvest storage } \\
\text { facility }\end{array}$ & 0.001 & 0.00 & 0.038 & 0.971 \\
\hline $\begin{array}{c}\text { MFTE (Manifest } \\
\text { Variable) }\end{array}$ & $0.161^{* * *}$ & 0.055 & 2.927 & 0.003 \\
\hline \multicolumn{5}{|c|}{ Model intercepts } \\
\hline MFTE & $0.246^{* * *}$ & 0.050 & 4.948 & 0.000 \\
\hline RT & $0.740^{* * *}$ & 0.070 & 10.551 & 0.000 \\
\hline \multicolumn{5}{|c|}{ Variances } \\
\hline MFTE & $0.055^{* * *}$ & 0.006 & 8.459 & 0.000 \\
\hline RT & $0.091^{* * *}$ & 0.009 & 9.729 & 0.000 \\
\hline \multicolumn{5}{|c|}{ Model Fit-Measures } \\
\hline Chisq & \multicolumn{4}{|c|}{3.376} \\
\hline$D f$ & \multicolumn{4}{|c|}{1.000} \\
\hline p-value & \multicolumn{4}{|c|}{0.046} \\
\hline$G f i$ & \multicolumn{4}{|c|}{0.999} \\
\hline$C f i$ & \multicolumn{4}{|c|}{0.953} \\
\hline Tli & \multicolumn{4}{|c|}{0.104} \\
\hline
\end{tabular}

The results show that efficiency and crop diversification contribute to the economic viability of farms. At the same time, if the household head is not involved fully in farm work, economic viability may not be achieved; this is similar to findings reported by [50,51]. This is connected to the relevance of labor as the main input in Sierra Leone agricultural production as well. When reviewing the determinants of efficiency, it is evident that higher efficiency is mainly achieved where there is less crop diversification and where fallow periods are not needed such as, for example, farms located in the eastern region that specialize in cash tree crops (i.e., coffee and cocoa trees). This is supported by the findings of [9]. In the case of the northern region, these findings entail that while rice specialization may increase technical efficiency, it will lead to lower economic viability levels. The results presents some evidence to the fact that availability of storage may reduce the drive for efficient production, when market access is limited. The findings 
also suggest that crop diversification by including market-oriented cash crops is a key livelihood strategy satisfying reproductive threshold conditions.

Given that the opportunity costs of farmers are close to zero in the northern region, increasing the efficiencies of staple crop production without market engagement could potentially lead to disguised unemployment and farmers may still fail to reach a threshold income level. It means that technical efficiency can be a sufficient but not necessary condition in determining economic viability of smallholder farming. There is a need to strike a balance between cash and food crop portfolios in the cultivation systems to ensure both economic viability and efficiency, particularly in the eastern region where cash tree crops offer higher market integration opportunities. In the northern region, the degree of crop diversification needs to be linked to commercial endeavors in order to increase economic viability. When it comes to diversification outside the farm, part time farming seems to reduce the economic viability of farming and, hence, caution must be taken when using part time non-farming activities to enhance economic viability in the research area. If generalized, results points to the need of moving-up (diversification and expansion) in farming activities for some farmers while others need to move-out of farming to non-farming activities.

Ultimately, the findings show that increased market access, reorientation of crops, and changing labor allocation could be more effective than technology transfer to enhance efficiencies of subsistence production, especially if the external support leads to further specialization on staple crops rather than market-oriented crops. Furthermore, future studies on how different socioecological drivers, including population, institutions, and agrarian characteristics influence the efficiency of these farming systems [52] will be highly useful for promoting the transition of these systems to sustainability. The study calls for revised theories of change in Sierra Leone and similar Sub-Saharan African countries. The most adequate course of action connects to promoting better market access for farmers and increasing the capability of farmers to better utilize their physical and social capitals in adopting the right mix of agricultural practices, crop preferences, technology choices, and livelihood strategies [53]. This is particularly challenging in the northern region, which exhibits a higher rate of autarky and self-consumption. Although it is not directly examined in the current study, enhancing their financial capital and legalizing land as collateral can obviously help the process.

\section{Conclusions}

Depending on the agroecological zone as well as access to key inputs and capitals, smallholders make different choices for crop portfolio management and, consequently, livelihood strategies. Such environmental and economic circumstances influence their capacity to achieve efficient production levels as well as to secure farm-level economic viability. This paper explores the determinants of both efficiency and economic viability at the smallholder level in the two most important agricultural regions of Sierra Leone, which share similar traits to other rural areas of SSA. There is a scarce literature linking reproductive thresholds that represent economic viability and the production efficiency of multiple crops. Most existing work assumes that the smallholders will continue doing what they currently do. The study presents an innovative methodological framework to understand diverging farming strategies and efficiency levels on the economic viability of farming in Sub-Saharan Africa and elsewhere. The hypothesis we test here is whether increasing efficiencies and diversification of existing farm enterprises lead to economic viability so that the farmers will stay in business. The answer we find is that efficiencies are only a part of the story and that the market orientation of the production portfolio is a dominating factor determining economic feasibility. The evidence indicates that smallholders who specialized in rice production in Sierra Leone are efficient, especially in terms of labor usage, but not viable in economic terms, while the increased presence of cash crops in the crop mix ensures greater economic viability. Findings suggest that interventions need to tackle not only yield increasing technologies but also market-oriented 
diversification that allows farmers to optimize production, securing an output level that fulfills self-consumption needs while promoting market participation (allowing lateral capital flows to food farming). Further, there is a group of farmers who could potentially exit agriculture if provided with alternatives. The evidence also indicates that, in the absence of alternatives outside agriculture, smallholders need diversified crop strategies in order to allow them to breach their respective reproductive thresholds, even though it is not as efficient as specializing in food crops. This calls for a dual policy approach that addresses farmers' internal needs for self-consumption (risk minimization with a balanced crop portfolio ensuring food security) while market access is ensured for encouraging market-oriented production (mainly through the reduction of associated transaction costs and establishment of accessible commercialization channels for high-value crops). Sierra Leone needs adequate investment in an enabling infrastructure and in increasing access to financial capital in combination with favorable changes in the agricultural policy framework to ensure the viability and increased efficiency of its farmers. Donor intervention in Sierra Leone must account for the tradeoffs between supporting crop diversification and supporting farming efficiencies as well the key determinants of the economic viability and efficiency of farming enterprises in this region.

Author Contributions: S.S.-M. contributed towards the development of concept, data collection and methodological approach (economic viability) as well as writing of results and discussion sections. T.S.A.-B. refined the concept (economic viability to technical efficiency) and methodology (Meta frontier and Structural equation Model) and contributed towards analysis, result writing, discussion and conclusions. S.A. contributed to methodology development and data analysis in " $R$ " software including meta-frontier and structural equation Models as well as to writing of results and discussion. S.S., J.A.S. and S.G.yP. contributed to development of concept, data collection as well as contributed towards result writing and discussion. All authors have read and agreed to the published version of the manuscript.

Funding: This research received no external funding.

Institutional Review Board Statement: Data was collected according the guidelines of Joint Research Center, European Commission.

Informed Consent Statement: Informed consent was obtained from all subjects involved in the study.

Data Availability Statement: The data presented in this study are available on request from the corresponding author.

Acknowledgments: Authors are thankful to the anonymous reviewers of the manuscript for their constructive suggestions and the farmer respondents of Sierra Leone.

Conflicts of Interest: The authors declare no conflict of interest.

\section{References}

1. Wang, P.; Deng, X.; Jiang, S. Global warming, grain production and its efficiency: Case study of major grain production region. Ecol. Indic. 2019, 105, 563-570. [CrossRef]

2. Amjath-Babu, T.S.; Krupnik, T.J.; Aravindakshan, S.; Arshad, M.; Kaechele, H. Climate change and indicators of probable shifts in the consumption portfolios of dryland farmers in Sub-Saharan Africa: Implications for policy. Ecol. Indic. 2016, 67, 830-838. [CrossRef]

3. Amjath-Babu, T.S.; Krupnik, T.J.; Kaechele, H.; Aravindakshan, S.; Sietz, D. Transitioning to groundwater irrigated intensified agriculture in Sub-Saharan Africa: An indicator based assessment. Agric. Water Manag. 2016, 168, 125-135. [CrossRef]

4. Collier, P.; Dercon, S. African Agriculture in 50Years: Smallholders in a Rapidly Changing World? World Dev. 2014, 63, 92-101. [CrossRef]

5. Chen, Z.; Huffman, W.E.; Rozelle, S. Farm technology and technical efficiency: Evidence from four regions in China. China Econ. Rev. 2009, 20, 153-161. [CrossRef]

6. Fan, S.; Rue, C. The Role of Smallholder Farms in a Changing World. In The Role of Smallholder Farms in Food and Nutrition Security; Gomez y Paloma, S., Riesgo, L., Louhichi, K., Eds.; Springer International Publishing: Cham, Germany, 2020; pp. 13-28.

7. Schultz, T.W. Changing Relevance of Agricultural Economics. Am. J. Agric. Econ. 1964, 46, 1004-1014. [CrossRef]

8. Abler, D.G.; Sukhatme, V.A. The "efficient but poor" hypothesis. Rev. Agric. Econ. 2006, 28, 338-343. [CrossRef] 
9. $\quad$ Frelat, R.; Lopez-Ridaura, S.; Giller, K.E.; Herrero, M.; Douxchamps, S.; Djurfeldt, A.A.; Erenstein, O.; Henderson, B.; Kassie, M.; Paul, B.K. Drivers of household food availability in sub-Saharan Africa based on big data from small farms. Proc. Natl. Acad. Sci. USA 2016, 113, 458-463. [CrossRef]

10. Food and Agriculture Organization of the United Nations (FAO). The State of Food and Agriculture, 2014: Innovation in Family Farming; Food and Agriculture Organization of the United Nations: Rome, Italy, 2014.

11. FAO. Guidelines for Agrarian Systems Diagnosis; FAO: Rome, Italy, 1999.

12. O'Donnell, C.J.; Rao, D.P.; Battese, G.E. Metafrontier frameworks for the study of firm-level efficiencies and technology ratios. Empir. Econ. 2008, 34, 231-255. [CrossRef]

13. Li, Q.; Amjath-Babu, T.; Zander, P. Role of capitals and capabilities in ensuring economic resilience of land conservation efforts: A case study of the grain for green project in China's Loess Hills. Ecol. Indic. 2016, 71, 636-644. [CrossRef]

14. Saravia Matus, S.L.; Gomez y Paloma, S. Farm viability of (semi) subsistence smallholders in Sierra Leone. Afr. J. Agric. Resour. Econ. 2014, 9, 165-182.

15. Mutabazi, K.D.; Amjath-Babu, T.; Sieber, S. Influence of livelihood resources on adaptive strategies to enhance climatic resilience of farm households in Morogoro, Tanzania: An indicator-based analysis. Reg. Environ. Chang. 2015, 15, 1259-1268. [CrossRef]

16. Sesay, A.; Tejan-Kella, M.; Thompson, A. Agricultural Sector, Background Review for the PRSP; Government of Sierra Leone: Freetown, Sierra Leone, 2004.

17. IFPRI. Rebuilding after Emergency: Revamping Agricultural Research in Sierra Leone after Civil War; International Food Policy Research Institute (IFPRI): Washington, DC, USA, 2009.

18. GEF. Integrating Adaptation to Climate Change into Agricultural Production and Food Security in Sierra Leone. Available online: https: / www.thegef.org/project/integrating-adaptation-climate-change-agricultural-production-and-food-securitysierra-leone (accessed on 22 January 2020).

19. Wadsworth, R.; Jalloh, A.; Lebbie, A. Changes in Rainfall in Sierra Leone: 1981-2018. Climate 2019, 7, 144. [CrossRef]

20. Schroth, G.; Läderach, P.; Martinez-Valle, A.I.; Bunn, C.; Jassogne, L. Vulnerability to climate change of cocoa in West Africa: Patterns, opportunities and limits to adaptation. Sci. Total Environ. 2016, 556, 231-241. [CrossRef] [PubMed]

21. Govereh, J.; Jayne, T.S. Cash cropping and food crop productivity: Synergies or trade-offs? Agric. Econ. 2003, 28, 39-50. [CrossRef]

22. Gomez y Paloma, S.; Acs, S.; Saravia Matus, S.; Baudouin, M.; Hites, G.; Sammeth, F. Rural Poverty Reduction and Food Security: The Case of Smallholders in Sierra Leone; Institute for Prospective and Technological Studies, Joint Research Centre: Seville, Spain, 2012.

23. Saravia-Matus, S.; Gomez y Paloma, S. Implementation challenges to the National Sustainable Agriculture Development Plan (NSADP) for (semi) subsistence farmers in Sierra Leone. Cah. Agric. 2015, 24, 240-245.

24. Unruh, J.D.; Turray, H. Land Tenure, Food Security and Investment in Postwar Sierra Leone; FAO LSP WP: Rome, Italy, 2006 ; Volume 22.

25. NSADP. National Sustainable Agriculture Development Plan 2010-2030; NSADP: Munich, Germany, 2009.

26. Ehui, S.K.; Spencer, D.S. Measuring the sustainability and economic viability of tropical farming systems: A model from sub-Saharan Africa. Agric. Econ. 1993, 9, 279-296.

27. Färe, R.; Grosskopf, S.; Norris, M.; Zhang, Z. Productivity growth, technical progress, and efficiency change in industrialized countries. Am. Econ. Rev. 1994, 84, 66-83.

28. Banker, R.D.; Charnes, A.; Cooper, W.W. Some models for estimating technical and scale inefficiencies in data envelopment analysis. Manag. Sci. 1984, 30, 1078-1092. [CrossRef]

29. Seiford, L.M.; Thrall, R.M. Recent developments in DEA: The mathematical programming approach to frontier analysis. J. Econom. 1990, 46, 7-38. [CrossRef]

30. Färe, R.; Grosskopf, S.; Logan, J.; Lovell, C.K. Measuring efficiency in production: With an application to electric utilities. In Managerial Issues in Productivity Analysis; Springer: Berlin/Heidelberg, Germany, 1985; pp. 185-214.

31. Olesen, O.; Petersen, N. Incorporating quality into data envelopment analysis: A stochastic dominance approach. Int. J. Prod. Econ. 1995, 39, 117-135. [CrossRef]

32. Wossink, A.; Denaux, Z.S. Environmental and cost efficiency of pesticide use in transgenic and conventional cotton production. Agric. Syst. 2006, 90, 312-328. [CrossRef]

33. Manjunatha, A.; Speelman, S.; Aravindakshan, S.; Ts, A.B.; Mal, P. Impact of informal groundwater markets on efficiency of irrigated farms in India: A bootstrap data envelopment analysis approach. Irrig. Sci 2016, 34, 41-52.

34. Cook, W.D.; Tone, K.; Zhu, J. Data envelopment analysis: Prior to choosing a model. Omega 2014, 44, 1-4. [CrossRef]

35. Battese, G.E.; Rao, D.P.; O'donnell, C.J. A metafrontier production function for estimation of technical efficiencies and technology gaps for firms operating under different technologies. J. Product. Anal. 2004, 21, 91-103. [CrossRef]

36. Aravindakshan, S.; Rossi, F.; Amjath-Babu, T.S.; Veettil, P.C.; Krupnik, T.J. Application of a bias-corrected meta-frontier approach and an endogenous switching regression to analyze the technical efficiency of conservation tillage for wheat in South Asia. J. Product. Anal. 2018, 49, 153-171. [CrossRef]

37. Charnes, A.; Cooper, W.W.; Rhodes, E. Measuring the efficiency of decision making units. Eur. J. Oper. Res. 1978, 2, 429-444. [CrossRef]

38. Geta, E.; Bogale, A.; Kassa, B.; Elias, E. Productivity and Efficiency Analysis of Smallholder Maize Producers in Southern Ethiopia. J. Hum. Ecol. 2013, 41, 67-75. [CrossRef]

39. Sherman, H.D.; Zhu, J. Service Productivity Management: Improving Service Performance using Data Envelopment Analysis (DEA); Springer: New York, NY, USA, 2006. 
40. Rodríguez-Díaz, J.; Camacho-Poyato, E.; López-Luque, R. Application of data envelopment analysis to studies of irrigation efficiency in Andalusia. J. Irrig. Drain. Eng. 2004, 130, 175-183. [CrossRef]

41. Coelli, T.J.; Rao, D.S.P.; O’Donnell, C.J.; Battese, G.E. An Introduction to Efficiency and Productivity Analysis; Springer: New York, NY, USA, 2005.

42. Galiano-Garrigós, A.; González-Avilés, Á.; Rizo-Maestre, C.; Andújar-Montoya, M.D. Energy efficiency and economic viability as decision factors in the rehabilitation of historic buildings. Sustainability 2019, 11, 4946. [CrossRef]

43. Krikser, T.; Zasada, I.; Piorr, A. Socio-economic viability of urban agriculture-A comparative analysis of success factors in Germany. Sustainability 2019, 11, 1999. [CrossRef]

44. Coppola, A.; Scardera, A.; Amato, M.; Verneau, F. Income levels and farm economic viability in Italian farms: An analysis of FADN data. Sustainability 2020, 12, 4898. [CrossRef]

45. Bollen, K.A.; Noble, M.D. Structural equation models and the quantification of behavior. Proc. Natl. Acad. Sci. USA 2011, 108, 15639-15646. [CrossRef]

46. Department for International Development (DFID). Sustainable Livelihoods Guidance Sheets; DFID: London, UK, $2001 ;$ p. 150.

47. Bogetoft, P.; Otto, L. Benchmarking with DEA, SFA, and R; Springer: New York, NY, USA, 2010.

48. Simar, L.; Zelenyuk, V. On testing equality of distributions of technical efficiency scores. Econom. Rev. 2006, 25, 497-522. [CrossRef]

49. Li, Q.; Maasoumi, E.; Racine, J.S. A nonparametric test for equality of distributions with mixed categorical and continuous data. J. Econom. 2009, 148, 186-200. [CrossRef]

50. Ofori-Bah, A.; Asafu-Adjaye, J. Scope economies and technical efficiency of cocoa agroforesty systems in Ghana. Ecol. Econ. 2011, 70, 1508-1518. [CrossRef]

51. Mutoko, M.C.; Hein, L.; Shisanya, C.A. Farm diversity, resource use efficiency and sustainable land management in the western highlands of Kenya. J. Rural Stud. 2014, 36, 108-120. [CrossRef]

52. Aravindakshan, S.; Krupnik, T.J.; Groot, J.C.J.; Speelman, E.N.; Amjath-Babu, T.S.; Tittonell, P. Multi-level socioecological drivers of agrarian change: Longitudinal evidence from mixed rice-livestock-aquaculture farming systems of Bangladesh. Agric. Syst. 2020, 177, 102695. [CrossRef]

53. Aravindakshan, S.; Krupnik, T.J.; Amjath-Babu, T.S.; Speelman, S.; Tur-Cardona, J.; Tittonell, P.; Groot, J.C.J. Quantifying farmers' preferences for cropping systems intensification: A choice experiment approach applied in coastal Bangladesh's risk prone farming systems. Agric. Syst. 2021, 189, 103069. [CrossRef] 